\title{
SIKAP ONLINE SHOPPING DAN NIAT PENCARIAN INFORMASI TERHADAP NIAT DAN PERILAKU BELANJA
}

\author{
Apriliani Kartika Setiowati \\ Magister Manajemen - Universitas Muhammadiyah Malang \\ E-mail: apriliani.kartika@gmail.com \\ Widayat \\ Fakultas Ekonomi dan Bisnis- Universitas Muhammadiyah Malang \\ E-mail:widayatumm@yahoo.com \\ Jasly By \\ Fakultas Ekonomi-Universitas Merdeka Pasuruan \\ E-mail: Jasly@yahoo.com
}

\begin{abstract}
This explanatory study aims to test and analyze how respondents attitudes towards online shopping effect, information gathering, shopping intention and behavior. To measure the attitudes toward online shopping, attributes associated to online shopping are used. Moreover, the websites revisits and shopping intensity through alternative channels are used to measure the behaviour of the respondents visiting intensity to shop online. Partial least square are used to analysis primary data attitudes toward online shopping, purpose to gather information online, shopping intention and shopping behaviour. The data was collected by using a questionnaire distributed to online shopping consumers through electronic mail. Sample size includes 100 respondents with judgmental sampling technique. The sample's respondents are members of an online fashion store, online shopping purchase between July and September 2011. The result of T-test shows that the attitude towards online shopping has positive effect on information searching intention and online shopping intention. Furthermore, the findings show that the purpose the respondent gathers information online has positive effect on online shopping intention. Lastly, shopping intention has significant effect on shopping behavior. The $Q$-square score resulted from the study is 0.9275. It means that the model in the study has the capacity to predict the possible correlation among the analyzed variables that consist of attitude, information gathering intention, shopping intention and shopping behavior.
\end{abstract}

Keywords: attitude toward online shopping, information searching intention, online shopping intention and online shopping behavior.

\section{PENDAHULUAN}

Dewasa ini bisnis dan perdagangan melalui internet semakin diminati dan berkembang cukup pesat. Tingginya minat pada bisnis berbasis internet tersebut seiring dengan perkembangan teknologi informasi dan karena Sistem bisnis tersebut ber- kembang karena menawarkan berbagai kemudahan dan kelebihan, diantaranya kecepatan dan komunikasi (Syarif, 2011), yang didukung oleh penggunaan internet semakin mudah. Pada masa lalu internet hanya dapat diakses melalui komputer, namun saat ini internet dapat diakses melalui telepon genggam. 
Bisnis dan belajanya melalui internet juga cukup berkembang di Indonesia. Hal ini terjadi seiring dengan tumbuhnya pengguna internet di Indonesia. Pada tahun 2010 jumlah pengguna internet di Indonesia meningkat dari sekitar 30 juta jiwa menjadi sekitar 45 juta jiwa. Pertumbuhan jumlah pengguna internet di tahun 2011 juga diprediksikan akan mengalami peningkatan yang sangat baik. Hal ini menjadi ladang yang sangat potensial bagi para pelaku bisnis online. Dengan semakin banyak orang yang menggunakan internet maka pasar dunia maya juga semakin terbuka. Menurut Syarief (2011) pertumbuhan bisnis online di Indonesia dipengaruhi oleh daya beli konsumen melalui internet yang meningkat.

Pada tahun 2010 jumlah penduduk yang melakukan online shopping hanya $6,3 \%$, namun pada pertengahan tahun 2011, meningkat dua kali lipat menjadi $12,7 \%$. Terlebih lagi, munculnya pasar potensial di facebook, seiring dengan meningkatnya jumlah pengguna situs jejaring sosial tersebut. Bahkan Sarie (2011) juga menuliskan bahwa 3 dari 10 member akunt facebook menggunakan jejaring sosial itu untuk mempromosikan barang dagangan mereka.

Menurut hasil Nielsen Global Online Survey (Syarif,2011) yang digelar Maret 2010 menunjukkan bahwa perilaku konsumen online shopping di Indonesia cukup unik. Di negara maju barang yang dibeli secara online adalah barang-barang elektronik atau produk IT, namun barang tersebut kurang laku di Indonesia. Justru produk fashion yang paling sering dibeli secara online. Sementara, Gunawan (2008) menuliskan bahwa pilihan produk yang dibeli secara online berkaitan dengan karakteristik konsumen itu sendiri, konsumen online shopping di Indonesia masih sensitif terhadap harga, mereka cenderung membeli produk yang memiliki harga yang lebih rendah. Selain itu konsumen online shopping di Indonesia cenderung tidak mudah percaya sehingga mereka membutuhkan banyak waktu untuk mencari informasi dan membanding-bandingkan produk pada beberapa web sebelum memutuskan untuk membeli.

Dilihat dari jenis produk yang diminati, konsumen online shopping di Indonesia cenderung membeli produk fashion. Menurut Theory of Planned Behavior, semakin besar keinginan yang dimiliki seseorang untuk berbelanja online maka semakin besar pula kemungkinan orang tersebut untuk berbelanja online. Sebaliknya, semakin lemah niat yang dimiliki seseorang untuk berbelanja online maka semakin kecil kemungkinan seseorang untuk berbelanja. Menurut Gibson dalam Prasetya (2005), perilaku terjadi karena adanya suatu sebab yang menggerakkan, mendorong atau bertindak. Ada dua faktor penting dari definisi tersebut, yaitu adanya penyebab yang menggerakkan yang berarti adanya suatu rangsangan atau stimulus. Kedua, adanya dorongan untuk bertindak yang berarti adanya suatu motivasi yang kuat yang diwujudkan dalam bentuk perilaku yang sesugguhnya. Dorongan untuk berperilaku itulah niat seseorang untuk berperilaku. Jadi niat belanja online berada dalam diri seseorang sehingga sulit untuk dilihat.

Online shopping merupakan hal yang relatif baru di Indonesia. Sehingga konsumen merasa perlu untuk mencari informasi mengenai berbagai produk yang ditawarkan sebelum memutuskan untuk membeli. Pada tahap ini konsumen akan berperan aktif untuk mencari informasi mengenai berbagai hal yang terkait online shopping. Web online shopping tidak hanya berfungsi sebagai tempat untuk bertransaksi tetapi juga sebagai sumber informasi bagi konsumen. Berbagai informasi yang diperoleh melalui web belanja tersebut akan diolah lebih lanjut sebelum memutuskan untuk berbelanja online.

Shim et al. (2001) menemukan hubungan antara maksud penggunaan internet untuk pencarian informasi dan maksud penggunaan internet untuk membeli secara online. Individu yang memiliki maksud yang lebih besar untuk menggunakan internet guna mencari informasi maka akan memiliki maksud yang lebih besar pula untuk melakukan pembelian melalui internet. Ia juga menemukan bahwa sikap konsumen terhadap cara belanja online memiliki pengaruh yang positif terhadap niat pencarian informasi melalui internet. Ketika konsumen memiliki sikap yang positif terhadap pengecer, maka besar kemungkinan bagi konsumen tersebut menunjukkan kesediaannya untuk mencari infor- 
masi produk dari pengecer tersebut sebelum memutuskan untuk membeli melalui saluran tersebut. Sedangkan Kim \& Park (2005) menyatakan bahwa terdapat hubungan positif antara sikap terhadap cara pembelian melalui toko online dan niat pembelian melalui toko online. Jadi sikap dapat berpengaruh langsung terhadap niat pembelian secara online tanpa melalui variabel niat pencarian informasi.

Konsumen biasanya memiliki kepercayan terhadap atribut suatu produk, dan atribut tersebut merupakan alat untuk membangun image yang melekat dalam produk tersebut. Sikap menggambarkan kepercayaan konsumen terhadap berbagai atribut tersebut dalam menilai produk. Bagi perusahaan tanggapan konsumen terhadap produk yang dihasilkannya adalah sangat penting, termasuk penilaian konsumen terhadap atribut-atribut produk. Penilaian konsumen ini akan mempengaruhi niat belanja konsumen terhadap suatu produk. Konsumen akan memilih produk yang mengandung atribut-atribut yang diyakininya relevan dengan yang dibutuhkannya.

Berdasarkan uraian tersebut menarik dilakukan penelitian mengenai sikap terhadap online shopping serta pengaruhnya pada niat pencarian informasi, niat belanja dan perilaku belanja". Penelitian ini bertujuan untuk menguji dan menganalisis pengaruh sikap terhadap online shopping pada niat pencarian informasi dan niat belanja online, untuk menguji dan menganalisis niat pencarian informasi terhadap niat belanja online, serta untuk menguji dan menganalisis pengaruh niat belanja online terhadap perilaku.

\section{TINJAUANPUSTAKA}

The Theory of Planned Behavior (TPB) (Ajzen, 1991) menyatakan bahwa niat merupakan variabel antara yang menyebabkan terjadinya perilaku dari suatu sikap maupun variabel lainnya. Salah satu faktor yang mempengaruhi niat adalah sikap terhadap perilaku. Menurut Assael (1998) sikap merupakan kecenderungan terhadap produk tertentu yang menyebabkan konsumen merespon baik atau tidak baik terhadap produk tertentu.
Menurut Schiffman dan Kanuk (2004) sikap terdiri atas tiga komponen, yaitu kognitif, afektif dan konatif. Komponen kognitif dari sikap menggambarkan pengetahuan dan persepsi terhadap suatu objek sikap. Komponen afektif merupakan komponen yang menggambarkan perasaan dan emosi seseorang terhadap suatu produk atau merek. Sedangkan komponen konatif adalah komponen yang menggambarkan kecenderungan dari seseorang untuk melakukan tindakan tertentu yang berkaitan dengan objek sikap (produk atau merek tertentu).

Shim et al. (2001) menuliskan bahwa sikap terhadap online shopping dapat dievaluasi melalui atribut yang melekat pada online shopping, Shim et al. (2001) menemukan bahwa sikap terhadap online shopping memiliki pengaruh yang positif terhadap niat pencarian informasi melalui internet. Hal ini menunjukkan bahwa toko online tidak hanya berfungsi sebagai saluran untuk bertransaksi bagi konsumen, tetapi juga berfungsi sebagai alat untuk mencari informasi. Ketika seorang konsumen memiliki sikap yang positif terhadap pengecer, maka besar kemungkinan bagi konsumen tersebut menunjukkan kesediaannya untuk mencari informasi produk dari pengecer tersebut sebelum memutuskan untuk membeli melalui saluran tersebut.

Dalam studi yang berbeda Kim dan Park (2005) menyatakan bahwa sikap terhadap cara pembelian melalui toko online memiliki pengaruh yang signifikan terhadap niat pembelian melalui toko online. Hal ini terjadi jika barang-barang yang ditawarkan melalui toko online tersebut merupakan barang yang memiliki tingkat resiko yang rendah, harga yang murah serta merupakan produk yang biasa dibeli. Konsumen cenderung melewati tahap pencarian informasi karena merasa kurang perlu untuk melakukannya, mereka cukup menerima informasi yang ada pada web belanja tanpa ada keinginan untuk mencari tahu lebih banyak lagi.

Niat merupakan mediator pengaruh berbagai faktor motivasional yang berdampak pada perilaku. Menurut Dharmmesta (1998) niat mencerminkan kemauan seseorang untuk melakukan tindakan tertentu. Niat dianggap sebagai penangkap atau 
perantara faktor-faktor motivasional yang memiliki dampak pada suatu perilaku. Dengan demikian, maka niat adalah paling dekat berhubungan dengan perilaku selanjutnya. Niat pencarian informasi merupakan seberapa besar keinginan individu untuk mencari informasi mengenai suatu produk atau merek melalui berbagai media yang ada. Sedangkan niat belanja adalah sejauh mana keinginan konsumen untuk melakukan transaksi pembelian suatu produk atau merek tertentu.

Hubungan antara maksud penggunaan internet untuk pencarian informasi dan maksud penggunaan internet untuk berbelanja secara online didasarkan pada model yang dikembangkan oleh Shim et al. (2001). Individu yang memiliki maksud yang lebih besar untuk menggunakan internet guna pencarian informasi, mungkin memiliki maksud yang lebih besar pula untuk menggunakan internet untuk berbelanja. Sebaliknya, individu yang memiliki niat lemah untuk mencari informasi melalui internet, maka akan cenderung memiliki niat yang lebih lemah pula untuk berbelanja online.

Niat akan diwujudkan dalam bentuk perilaku, Peter dan Olson (1999) mendefinisikan perilaku konsumen sebagai interaksi yang dinamis antara pengaruh dan kognisi, perilaku dan kejadian disekitar kita dimana manusia melakukan aspek pertukaran dalam hidup mereka. Dari definisi tersebut menekankan bahwa perilaku konsumen bersifat dinamis yang berarti seorang konsumen, grup konsumen serta masyarakat luas selalu berubah dan bergerak sepanjang waktu. Hal kedua yang ditekankan Peter dan Olson adalah perilaku konsumen melibatkan interaksi antara pengaruh kognisi, perilaku dan kejadian sekitar. Dan hal terakhir yang ditekankan pada definisi tersebut bahwa perilaku konsumen melibatkan pertukaran. Chanaka (2004) menuliskan bahwa perilaku belanja online dapat diukur menggunakan tiga indikator, yaitu kunjungan ke toko online (browsing), pengulangan pembelian (repatronage), dan belanja melalui saluran lain (switching). merupakan aktifitas individu dalam menjelajahi berbagai situs internet. Berangkat dari kajian pustaka tersebut hipotesis yang diajukan pada penelitian ini meliputi:
H1: Sikap terhadap online shopping berpengaruh signifikan pada niat pencarian informasi secara online.

H2: Sikap terhadap online shopping berpengaruh signifikan pada niat belanja online

H3: Niat pencarian informasi berpengaruh signifikan terhadap niat belanja online.

H4: Niat belanja online berpengaruh signifikan terhadap perilaku belanja secara online.

\section{METODE PENELITIAN}

Jenis penelitian ini adalah penelitian eksplanatori dengan menggunakan metode survey. Sampel yang digunakan adalah 100 responden yang diambil dengan metode judgmental sampling. Karakteristik anggota sampel adalah member web belanja online produk fashion, memiliki pengalaman belanja online lebih dari sekali dan berbelanja online selama bulan Juli sampai dengan September 2011. Data yang digunakan yakni data primer yang berupa jawaban kuesioner dari responden. Kuesioner tersebut dikirim kepada responden melalui email untuk memperoleh tanggapan. Dalam penelitian ini digunakan 1 variabel eksogen yaitu sikap terhadap online shopping dan 3 variabel endogen, yaitu niat pencarian informasi, niat belanja dan perilaku belanja. Untuk mencapai tujuan penelitian maka digunakan partial least square sebagai alat analisis.

\section{HASIL PENELITIAN DAN PEMBAHASAN}

Hasil penelitian menunjukkan bahwa karakteristik responden online shopping didominasi oleh perempuan dan memiliki rentang usia antara 16 tahun sampai 25 tahun. Sebagian besar dari mereka berstatus sebagai pelajar atau mahasiswa. Produk yang paling sering dibeli oleh responden secara online adalah tas dan memiliki kisaran harga antara Rp. 100.000 sampai dengan 300.000.

Uji outer model menunjukkan bahwa semua item pengukuran dalam penelitian dinyatakan valid dan reliabel. Kriteria yang digunakan untuk menguji 
outer model adalah convergent validity, discriminant validity dan composite reliabiliti. Convergent validity digunakan untuk menguji apakah indikatorindikator yang digunakan telah mengukur konstruk atau dimensi secara akurat. Sedangkan Discriminant validity digunakan untuk menguji apakah indikator suatu konstruk tidak berkorelasi tinggi dengan indikator dari konstruk lain atau paling tidak indikator tersebut berkorelasi lebih rendah dengan indikator-indikator konstruk yang lain. Setelah semua item pengukuran dinyatakan valid dan reliabel maka langkah selanjutnya adalah menguji inner model atau model struktural.

Inner model dinilai melalui tiga kriteria, yaitu $R$-square, $Q$-square test dan uji koefisien parameter. Nilai $R$-square pada variabel niat pencarian informasi sebesar 0,572, nilai ini menunjukkan bahwa variabel niat pencarian informasi mampu dijelaskan oleh variabel sikap terhadap belanja online dalam penelitian sebesar $57,2 \%$. Sedangkan 42,8\% merupakan kontribusi dari variabel lain yang tidak disertakan dalam penelitian. Pada the theory planned of behavior terdapat tiga variabel yang digunakan untuk menjelaskan variabel niat. Sedangkan dalam penelitian ini hanya menggunakan 1 variabel saja untuk menjelaskan variabel niat. Maka dirasa wajar jika nilai $R$-square untuk variabel niat berada pada kategori moderat.

$R$-square untuk niat belanja sedikit lebih tinggi jika dibandingkan niat pencarian informasi, yaitu 0,592 . Hasil tersebut menunjukkan bahwa niat belanja telah mampu dijelaskan oleh variabel sikap dan niat pencarian informasi yang dipakai dalam penelitian sebesar 59,2\%. Sedangkan sisanya dijelaskan oleh variabel lain yang belum dimasukkan dalam desain penelitian ini. Variabel dependen yang trakhir adalah perilaku belanja, dengan nilai $R$-square sebesar 0,584. Dengan demikian maka variabel perilaku hanya mampu dijelaskan oleh variabel niat belanja sebesar 58,4\%. Masih banyak variabel lain yang perlu dimasukkan dalam penelitian agar mampu menghasilkan nilai $R$-square yang lebih tinggi lagi. Nilai $R$-square untuk setiap variabel dapat dilihat pada tabel 1 .
Tabel 1. Nilai $R$-square Pada Setiap Variabel

\begin{tabular}{ll}
\hline Variabel & R Square \\
\hline Niat Pencarian Informasi & 0.572335 \\
Niat Belanja & 0.592597 \\
Perilaku Belanja & 0.584132 \\
\hline
\end{tabular}

Semakin tinggi nilai $R$-square yang dihasilkan oleh variabel endogen, maka semakin baik model yang dipakai dalam penelitian. Secara keseluruan model struktural dalam penelitian ini berada dalam kategori moderat, karena memiliki nilai $R$-square lebih besar dari 0,33 . Model yang moderat berarti bahwa model yang diajukan dalam penelitian sudah layak untuk dipakai.

$Q$-square test digunakan untuk mengukur seberapa baik nilai observasi dihasilkan oleh model dan juga estimasi parameternya. Rentang nilai Qsquare test adalah lebih dari nol dan kurang dari satu $(0<\mathrm{Q} 2<1)$, semakin mendekati nilai 1 maka model semakin baik. Nilai $Q$-square yang dihasilkan dalam penelitian ini menunjukkan bahwa model penelitian merupakan model yang baik, karena memiliki nilai sebesar 0,9275 . Nilai tersebut telah mendekati angka 1 sebagaimana yang telah ditetapkan pada kriteria penilaian model. Model yang baik adalah model yang mampu memprediksi kemungkinan hubungan antara variabel laten eksogen dan laten endogen. Berdasarkan nilai $Q$ square maka dinyatakan bahwa model dalam penelitian ini telah mampu memprediksi dengan baik kemungkinan hubungan antar variabel penelitian yang meliputi sikap terhadap belanja online, niat pencarian informasi, niat belanja dan perilaku belanja.

Koefisien parameter digunakan untuk menentukan arah hubungan antara variabel laten independen dengan laten dependennya. Tabel 2 dengan jelas menunjukkan bahwa semua koefisien parameter hubungan antara variabel eksogen terhadap variabel endogen adalah bernilai positif. Nilai positif tersebut mengindikasikan bahwa variabel laten eksogen berpengaruh secara positif terhadap variabel laten endogen. Koefisien parameter yang tertinggi adalah koefisien hubungan antara niat belanja terhadap perilaku belanja, yaitu sebesar 
0,764. Dalam The Theory Of Planned Behavior dengan jelas disebutkan bahwa niat berperilaku merupakan prediktor terkuat yang akan menentukan perilaku di masa yang akan datang. Dengan demikian maka besarnya niat atau keinginan konsumen untuk berbelanja online akan menentukan perilaku belanja. Semakin besar niat untuk belanja online maka akan semakin besar kemungkinan niat tersebut terwujud dalam bentuk perilaku belanja melalui toko online, begitu juga sebaliknya.

Tabel 2. Nilai Path Coefficients setiap Jalur Hubungan Variabel Penelitian

\begin{tabular}{lc}
\hline \multicolumn{1}{c}{ Jalur Hubungan } & Path Coefficients \\
\hline Sikap terhadap niat pencarian informasi & 0.756528 \\
Sikap terhadap niat belanja & 0.477276 \\
Niat pencarian informasi terhadap niat belanja & 0.342616 \\
Niat belanja terhadap perilaku belanja & 0.764286 \\
\hline
\end{tabular}

Dari keempat pola hubungan antara laten eksogen dengan laten endogen, hubungan antara niat pencarian informasi terhadap niat belanja memiliki koefisien parameter terendah, yaitu 0,343. Pada kasus pengulangan belanja seorang konsumen akan melewatkan tahap pencarian informasi. Sehingga konsumen tidak perlu meluangkan waktu lebih untuk mencari informasi, karena informasi telah didapatkan pada aktivitas belanja sebelumnya. Hal tersebut juga bisa terjadi jika produk yang dibeli memiliki resiko rendah sehingga tidak perlu mencari informasi secara mendetail, konsumen hanya menerima informasi pada web tanpa menggali informasi lebih dalam lagi dari toko online.

Dalam penelitian ini diajukan empat hipotesis, dan untuk mengujinya maka digunakan uji T. Hasil pengujian menunjukkan bahwa semua hipotesis yang diajukan dapat diterima. Karena setiap parameter hubungan memiliki T hitung yang lebih besar dari nilai $\mathrm{T}$ tabel (signifikansi 5\% $\mathrm{T}$ tabel = 1,96). Secara lengkap hasil pengujian hipotesis penelitian disajikan pada tabel 3

Tabel 3 Pengujian Hipotesis Penelitian

\begin{tabular}{lccc}
\hline Hipotesis & T hitung & T tabel & Keterangan Hipotesis \\
\hline $\begin{array}{l}\text { H1: Sikap terhadap online shopping } \\
\text { berpengaruh signifikan pada niat } \\
\text { pencarian informasi secara online. }\end{array}$ & 16.814298 & 1.96 & Diterima \\
$\begin{array}{l}\text { H2: Sikap terhadap online shopping } \\
\text { berpengaruh signifikan pada niat } \\
\text { belanja } \text { online. }\end{array}$ & 2.010115 & 1.96 & Diterima \\
$\begin{array}{l}\text { H3: Niat pencarian informasi } \\
\text { berpengaruh signifikan terhadap niat } \\
\text { belanja } \text { online. }\end{array}$ & 3.354473 & 1.96 & Diterima \\
$\begin{array}{l}\text { H4: Niat belanja } \text { online berpengaruh } \\
\text { signifikan terhadap perilaku belanja } \\
\text { secara } \text { online. }\end{array}$ & 11.912296 & 1.96 & Diterima \\
\hline
\end{tabular}


Penelitian ini menguji empat jalur antar variabel, yaitu sikap terhadap online shopping pada niat pencarian informasi, sikap terhadap online shopping pada niat belanja, niat pencarian informasi pada niat belanja serta niat belanja pada perilaku belanja. Jalur pertama adalah jalur antara sikap terhadap online shopping pada niat pencarian informasi secara online. Hasil penelitian menunjukkan bahwa sikap terhadap online shopping berpengaruh positif terhadap niat pencarian informasi. Perubahan sikap konsumen terhadap online shopping akan berpengaruh pada niat yang dimiliki untuk mencari informasi melalui toko online. Semakin baik sikap yang dimiliki konsumen terhadap atribut online shopping maka niat yang dimiliki konsumen untuk mencari informasi secara online akan meningkat. Hasil ini sejalan dengan penelitian sebelumnya yang dilakukan oleh Kim dan Park (2005).

Jalur kedua yang diuji dalam penelitian ini adalah pengaruh sikap terhadap online shopping pada niat belanja. Hasil penelitian menunjukkan bahwa sikap terhadap online shopping berpengaruh pada niat belanja. Pengaruh yang dimiliki adalah bernilai positif, sehingga semakin baik sikap konsumen terhadap belanja online maka niat yang dimiliki oleh konsumen untuk berbelanja online akan meningkat. Hasil ini mendukung temuan sebelumnya yang disampaikan oleh Kim dan Park (2005). Secara teori sikap merupakan salah satu prediktor niat untuk berperilaku.

Sikap dapat berpengaruh secara langsung terhadap niat belanja. Misalnya, dalam kasus pengulangan pembelian konsumen memiliki kecenderungan untuk melewatkan tahap pencarian informasi. Konsumen akan mengandalkan informasi yang telah didapatkan pada pengalaman sebelumnya. Konsumen akan melewatkan tahap pencarian informasi jika barang yang dibeli memiliki resiko yang relatif rendah. Konsumen cenderung hanya menerima informasi yang tertera pada website online shopping tanpa menggali informasi lebih dalam lagi mengenai produk maupun penyedia jasa.

Jalur ketiga adalah jalur antara niat pencarian informasi dan niat belanja online. Hasil penelitian menunjukkan bahwa niat pencarian informasi berpengaruh signifikan terhadap niat belanja online. Hasil ini sejalan dengan penelitian yang dilakukan oleh Kim dan Park (2005). Dalam proses pengambilan keputusan, konsumen akan melalui tahap pencarian informasi sebelum memutuskan untuk membeli atau tidak. Jadi niat belanja secara online akan didahului oleh niat pencarian informasi melalui internet. Semakin kuat niat yang dimiliki konsumen untuk mencari informasi secara online maka semakin kuat pula niat yang dimiliki untuk berbelanja online. Hal ini bisa terjadi karena konsumen akan terpengaruh oleh stimulus yang dibelikan toko online melalui informasi yang diterima konsumen melalui web belanja online.

Jalur terakhir dalam penelitian ini adalah jalur antara niat belanja dan perilaku. Hasil pengujian menunjukkan bahwa niat belanja online berpengaruh signifikan terhadap perilaku belanja. Hal ini sejalan dengan teori yang disampaikan oleh Ajzen (1991) yang menyatakan niat merupakan prediktor utama bagi perilaku. Konsumen dengan niat yang kuat akan cenderung mewujudkan niat tersebut melalui tindakan. Jadi perilaku belanja online akan ditentukan oleh kuat lemahnya niat yang dimiliki oleh seseorang untuk berbelanja.

\section{SIMPULAN}

Sebuah model sikap terhadap belanja onlineniat pencarian informasi-niat belanja-perilaku belanja digunakan menguji hubungan antara variabel laten eksogen dengan variabel laten endogen. Model struktural menunjukkan bahwa sikap berpengaruh positif terhadap niat pencarian informasi dan niat belanja. Semakin besar nilai sikap konsumen terhadap atribut yang melekat pada belanja online, maka akan semakin kuat niat yang dimiliki konsumen untuk mencari informasi dan melakukan aktivitas belanja. Niat pencarian informasi berpengaruh signifikan terhadap niat belanja. Konsumen yang memiliki niat pencarian informasi lebih kuat akan cenderung memiliki niat belanja secara online yang lebih kuat pula jika dibandingkan dengan konsumen yang memiliki niat pencarian informasi yang lebih rendah. 
Model struktural juga menunjukkan bahwa niat belanja berpengaruh signifikan terhadap perilaku. Perilaku belanja online digambarkan melalui tiga aktifitas, yaitu intensitas kunjungan pada toko online, intensitas pengulangan belanja dan intensitas belanja melalui saluran lain. Semakin kuat niat belanja yang dimiliki seseorang, maka semakin besar kemungkinan orang tersebut untuk berlamalama mencari informasi melalui web belanja online, mengulangi aktifitas belanja dan mengurangi aktifitas belanja melalui saluran yang lain. Nilai $Q$-square yang dihasilkan dalam penelitian ini menunjukkan bahwa model penelitian merupakan model yang baik dan dapat dipertahankan, karena memiliki nilai sebesar 0,9275. Berdasarkan nilai $Q$-square maka dinyatakan bahwa model dalam penelitian ini telah mampu memprediksi dengan baik kemungkinan hubungan antar variabel penelitian yang meliputi sikap, niat pencarian informasi, niat belanja dan perilaku belanja.

Hasil penelitian menunjukkan bahwa sikap terhadap belanja online berpengaruh signifikan dan positif terhadap niat pencarian informasi dan niat belanja. Sehingga diharapkan pada pelaku bisnis online untuk senantiasa meningkatkan kepercayaan konsumen terhadap cara belanja online melalui berbagai atribut yang melekat pada online shopping. Pelaku bisnis online dapat menggunakan web belanja online yang dimiliki sebagai media untuk berpromosi, tidak hanya sebagai media untuk bertransaksi. Informasi yang disediakan pada web belanja online bisa dibuat semenarik munkin sehingga dapat menjadi tempat yang nyaman dan menyenangkan untuk dikunjungi. Untuk penelitian selanjutnya dirasa perlu untuk menambahkan variabel ditambahkan variabel norma subjektif dan kontrol perilaku sebagai laten independen sebagaimana yang disampaikan dalam The Theory Of Planned Behavior. Selain itu juga disarankan untuk menggunakan skala pengukuran perilaku belanja yang lebih jelas, misalnya menggunakan skala nominal. Karena sebenarnya perilaku merupakan tindakan nyata sehingga sangat mudah untuk mengetahui dan mengukur perilaku tersebut.

\section{DAFTAR PUSTAKA}

Ajzen, Icek (1991). The Theory of Planned Behavior, Organization Behavior and Human Decision Processess. 50: 179-211

Dharmesta, B.S. (1998). Theory of Planned Behaviour dalam Penelitian Sikap, Niat dan Perilaku Konsumen. Kelola Gajah Mada University Business. Vol 8, No. 18: 85-103 Gunawan, Erick (2008). Karakteristik Konsumen Online di Indonesia. diakses 27 Agustus 2011. http://artikelweb.blogspot.com Jayawerdhena, Chanaka (2004). Personal Value's influence on E-shopping Attitude and Behaviour. Journal of Internet Research. Vol 14, No. 2: 127-138

Kim, Jihyun dan Park, Jihye (2005). A Consumer Shopping ChannelExtention Model: Attitude Shift Toward the Online Store. Journal of Fashion Marketing and Management. Vol 9, No. 1: 106-121

Peter, J. Paul dan Jerry C. Olson (1999). Consumer Behavior; 4th. Jakarta: Erlangga

Prasetya, Yudhi (2005). Analisis Pengaruh Sikap Terhadap Perilaku, Norma Subyektif, dan Kontrol Kepemilikan yang Dirasakan Terhadap Niat dan Perilaku Konsumen. Jurnal Investasi. Vol 1, No. 1: 79-88

Sarie (2011). Online Shopping Mulai Marak di Indonesia. diakses 12 Maret 2011. http:// www.techno.okezone.com

Shim, et al (2001). An Online Prepurchase Intentions Model: The Role of Intentions to Search. Journal of Retailing. 77: 397-416

Syarief (2011). Orang Indonesia Mulai sering Belanja Online. Diakses 12 Maret 2011. http://www.300ribu.com 